\title{
Diyarbakır ekolojik koşullarında tescilli bazı susam (Sesamum indicum L.) çeşitlerinin tarımsal ve kalite özelliklerinin araştırıması
}

Investigation of agricultural and quality caracteristics of some registered sesame (Sesamum indicum L.) cultivars in Diyarbakır ecological conditions

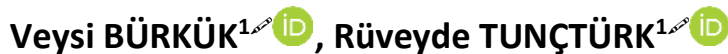

${ }^{1}$ Van Yuzuncuyil University, Faculty of Agriculture, Department of Field Crops, Van, Turkey.

MAKALE BILGISI / ARTICLE INFO

Makale tarihçesi / Article history:

DOI: $10.37908 /$ mkutbd.740682

Geliş tarihi /Received:21.05.2020

Kabul tarihi/Accepted:23.10.2020

\section{Keywords:}

Cultivar, oil content, Sesamum indicum L., yield.

\footnotetext{
Corresponding author: Rüveyde TUNÇTÜRK

$\bowtie$ : ruveydetuncturk@yyu.edu.tr
}

\author{
ÖZET / A B STR A C T
}

Atıf / Citation: Bürkük V, Tunçtürk V (2021) Diyarbakır ekolojik koşullarında tescilli bazı susam (Sesamum indicum L.) çeşitlerinin tarımsal ve kalite özelliklerinin araştırılması. MKU. Tar. Bil. Derg. 26(1) : 98-105. DOI: 10.37908/mkutbd.740682

\section{GíRiş}

Bir ülkenin temel ihtiyaçlarından biri olan yağ sanayisi, tarıma dayalı sanayi faaliyetlerinden biri olup ham maddesini yağı tohumlu bitkiler oluşturmaktadır. 2018 yılında; dünya yağıı tohum üretimi çok yıllık bitkiler hariç olmak üzere 574 milyon ton olup, bitkisel ham yağ üretim miktarı 195 milyon tondur. Ayrıca dünyada toplam 212 milyon ton ham yağ üretimi yapılmış olup, bu miktarın \%92.0'si yani 195.0 milyon tonu yağlı tohumlardan, \%8.0'i yani 17.0 milyon tonu ise hayvansal kaynaklardan sağlanmaktadır (Anonim, 2018; Arıoğlu ve ark., 2020).

Yağ bitkilerinin üretimi bakımından Türkiye' deki önemli 
potansiyelin değerlendirilmesi ile hem ülkemizin gereksinim duyduğu yağ ihtiyacı karşılanacak ve hem de \%55-65 atıl kapasite ile çalışan yağ üretim sektörüne önemli katkı sağlanacaktır. Son yıllarda yağlı tohum üretiminin yetersiz olması sebebiyle, önemli düzeyde olan ham yağ açığını daraltabilmek, ithalat ile döviz kaybınının önüne geçebilmek, işlenen yağın ihraç edilmesi ile, ülkemize döviz girdisi sağlamak ve çiftçilerin gelir seviyesini yükseltebilmek için, yağlı tohumların üretimi konusunda gerekli önlemlerin alınması önem arz etmektedir. Ülkemizde yağ bitkisi üretiminin \%87.2' sini ayçiçeği ve çiğit oluşturmaktadır. Soya, kolza ve aspir üretimi ise beklenen seviyelerde gerçekleşmemiştir. Türkiye' de yağ bitkisi üretimine ayrılan alan, toplam ekilebilir alanların sadece \%4.7' sini oluşturmaktadır. Bu sebeple yerli üretimden sağlanan yağlı tohum miktarı, ülkenin ihtiyaçlarına cevap veremediği için, her yıl yurt dışından önemli miktarda yağlı tohum ile ham yağ ithal edilmektedir (Arıoğlu ve ark., 2020).

2018 yılı verilerine göre, dünya susam ekiliş alanı 11743 382 ha, üretim miktarı 6015573 milyon ton ve verimi $51.23 \mathrm{~kg} / \mathrm{da}$ ' dır (Anonim, 2020a). Ülkemizde ise 2019 yılı verilerine göre; susam ekiliş alanı 248604 da, üretim miktarı 16893 ton ve verimi ise $68 \mathrm{~kg} / \mathrm{da}$ ' dır (Anonim, $2020 b)$. Susam tohumu \%50-60 oranında yağ ve \% 25 protein içermektedir. Karbonhidrat içeriği ise yaklaşık \% 14-15 civarındadır. Yağında yaklaşık olarak \% 35-45 arasında oleik ve linoleik asit bulunmaktadır. Ayrıca, sesamolin (\% 0.3- 0.5 ) ve sesamin (\% $0.5-1.5$ ) gibi sekonder maddeler içermesi nedeniyle susam yağı oksitlenmeye karşı oldukça dayanıklıdır. Özellikle de sesamin kandaki kolesterol düzeyini düşürmede önemli bir etkiye sahiptir (Baydar, 2005). Yağ oranı yüksek olan susam tohumları yağ ve tahin üretiminde, az olanlar ise simit ve bisküvi yapımında değerlendirilmektedir. Susam bitkisi dünyada yağ üretimi için kullanılsa da Türkiye ve diğer Ortadoğu ülkelerinde simit, tahin, bisküvi ve helva üretiminde kullanılmaktadır. Ayrıca, susam yağı; yemeklik, sabun, ilaç ve kozmetik sanayisinde kullanılmaktadır. Küspesinden ise hayvan yemi olarak yararlanılmaktadır.

Susam yağının değerli bir yağ olduğu ve susamın değişik alanlarda kullanımı dikkate alındığında susam tarımının önemi anlaşılmakta ve birim alandan alınan verimin ve kalitesinin arttırılması gerektiği ortaya çıkmaktadır. Türkiye'de susam tarımının yaygınlaşması ve gelişmesi için bölgeye uygun sertifikalı çeşitlerin kullanılmasının yanı sıra uygulanan kültürel faaliyetlerin uygun zamanda ve doğru yapılması gerekmektedir (Gençer ,1993).

Bu çalışmanın amacl; ülkemizde ekim alanı sürekli bir azalma gösteren ve aynı zamanda geleneksel tüketim besinlerimizden biri olan ve ülke içindeki tüketimin çoğunu ithalatla karşılamakta olduğumuz susam bitkisine ait Türkiye'de yetiştirilen bazı tescilli çeşitlerin Diyarbakır ekolojik koşullarına adaptasyonunun belirlemek ve yöreye uygun çeşitleri tespit etmektir.

\section{MATERYAL ve YÖNTEM}

Deneme 2017 yılında ikinci ürün olarak, DiyarbakırKayapınar (Çölgüzeli Mahallesi) ilçesinde çiftçi koşullarında yürütülmüştür. Araştırmada tohumluk materyali olarak Güneydoğu Anadolu Araştırma Enstitüsü (Hatipoğlu, Boydak ve Arslanbey), Batı Akdeniz Tarımsal Araştırma Enstitüsü (Özberk82 ve Muganlı57) ve Ege Tarımsal Araştırma Enstitüsü (Tanas, Kepsut99, Cumhuriyet99, Orhangazi99 ve Sarısu)'nden temin edilmiş on tescilli susam çeşidi kullanılmıştır.

Deneme alanı toprakları killi ve tuzsuz $(0.009 \mu \mathrm{S} / \mathrm{cm})$ yapıda olup hafif alkali (7.69) reaksiyonludur. Organik madde (\% 0.88) bakımından yetersiz, kireç (\% 15.36) bakımından ise orta düzeydedir (Anonim, 2019).

Deneme, Tesadüf Blokları Deneme Deseni' ne göre üç tekerrürlü olarak kurulmuştur. Araştırmada 10 tescilli susam çeşidi (Arslanbey, Boydak, Hatipoğlu, Sarısu, Tanas, Orhangazi-99, Kepsut 99, Muganlı 57, Özberk 82 ve Cumhuriyet 99) kullanılıştır. Toplam deneme alanı (37x16) $592 \mathrm{~m}^{2}$, parsel boyutları ise $2.8 \mathrm{~m} \times 4.0 \mathrm{~m}$ (11.2 $\mathrm{m}^{2}$ ) büyüklüğünde ve her blokta 10 parsel ve her parsel 4 sıradan oluşmuştur. Ekim öncesi sıra arası $70 \mathrm{~cm}$ olacak şekilde markör çekilerek sıralar belirlenmiştir. Sıra üzeri mesafe ise $10 \mathrm{~cm}$ olarak ayarlanmıştır. Dekara $600 \mathrm{~g}$ tohumluk hesabıyla her parsele $7 \mathrm{~g}$ tohum ile ekim 1.5$2.5 \mathrm{~cm}$ derinliğinde markörle açılan çizilere elle yapılmıştır. Denemede bloklar arası $2 \mathrm{~m}$ ve parseller arası mesafe $1 \mathrm{~m}$ olarak düzenlenmiştir. Her parsele eşit olmak koşuluyla, ekim ile birlikte $10 \mathrm{~kg} / \mathrm{da}$ azot ve fosfor gübrelemesi yapılmıştır. Gübre kaynağı olarak 20-20-0 kompoze NP gübresi kullanılmıştır. Sulama yöntemi olarak yağmurlama sulama sisteminden yararlanılmıştır. Gereklilik durumuna göre; çapalama işlemi tekrarlanmıştır. Hasat tarihi çeşitlerin farklı olgunlaşma durumuna göre 20.09.2017-25.09.2017 tarihleri arasında yapılmıştır. Hasat bitkilerin toprak üstü aksamının sarardığı dönemde yapılmıştır. Parseli oluşturan 4 sıradan her iki yandaki birer sıra ve sıra başlarından $50 \mathrm{~cm}$ kenar tesiri gözlem dışı bırakıldıktan sonra bütün işlemler geriye kalan $5.2 \mathrm{~m}^{2}(3 \mathrm{~m} \times 1.4 \mathrm{~m})$ alan üzerinden yapılmıştır.

Deneme tarlası ilkbaharda pulluk ile derin sürüm yapıldıktan sonra ekimden hemen önce yüzlek bir sürüm yapılmak suretiyle ekime hazır hale getirilmiştir. Ekim işlemi 30 Mayıs 2017 tarihinde 1.5-2.5 cm derinliğe el ile yapılmıştır. Bitkilerin çıkışından 10-15 gün sonra yabancı 
ot mücadelesi, toprağın gevşetilmesi ve karıkların hafifçe oluşturulması için elle hafif bir çapalama yapılmıştır. Bitkilerin 3-4 yapraklı $(10-15 \mathrm{~cm})$ oldukları dönemde seyreltme işlemi, çiçeklenme döneminde ise boğaz doldurma ve çapalama yapılmıştır. Susam hasadında söküm, baskı, gümül ve silkme işlemi elle yapılmıştır.

Araştırma sonucunda elde edilen veriler Tesadüf Blokları Deneme Deseni' ne göre varyans analizine tabi tutularak ortalamalar arasındaki farklılıklar Duncan Çoklu Karşılaştırma Yöntemi' ne göre belirlenmiştir (Düzgüneş ve ark., 1987). Korelasyon analizleri için IBM SPSS istatistik (Version 22) programından yararlanılmıştır. Verilerin normal dağılıma sahip olması durumunda Pearson korelasyon katsayısı, iki sayısal ölçüm arasında doğrusal bir ilişki olup olmadığını, varsa bu ilişkinin yönünü ve şiddetinin ne olduğunu belirlemek için kullanılan bir istatistiksel yöntemdir (IBM Corp., 2013).

\section{BULGULAR ve TARTIŞMA}

Tablo 1 incelendiğinde bitki boyu bakımından çeşitler arasında \% 5 düzeyinde istatistiksel olarak önemli farklılıkların olduğu görülmektedir. Denemede en uzun bitki boyu Özberk-82 $(174.6 \mathrm{~cm})$ susam çeşidinden elde edilirken, Sarısu çeşidi $(166.7 \mathrm{~cm})$ ile aralarında istatistiksel olarak önemli bir farklılığın olmadığı aynı Duncan grubunda yer aldığı belirlenmiştir. En kısa bitki boyu ise $133.2 \mathrm{~cm}$ ile Arslanbey çeşidinden elde edilmiştir.

Tablo 1. Susam çeşitlerinde bitki boyu, ilk dal yüksekliği, yan dal sayısı, kapsül sayısı ve tohum sayısı ortalama değerleri ve Duncan grupları

Table 1. Average values plant height, first branch height, number of branches, number of capsule and number of seeds in sesame varieties and Duncan groups

\begin{tabular}{|c|c|c|c|c|c|}
\hline Çeşitler & Bitki boyu $(\mathrm{cm})$ & $\begin{array}{l}\text { İlk dal } \\
\text { yüksekliği } \\
\text { (cm) }\end{array}$ & $\begin{array}{l}\text { Yan dal sayısı } \\
\text { (adet/bitki) }\end{array}$ & $\begin{array}{l}\text { Kapsül sayısı } \\
\text { (adet/bitki) }\end{array}$ & $\begin{array}{l}\text { Tohum sayısı } \\
\text { (adet/kapsül) }\end{array}$ \\
\hline Tanas & $161.4 \mathrm{ab}$ & $14.8 \mathrm{f}$ & $5.53 \mathrm{~b}$ & $162.3 \mathrm{a}$ & $74.22 \mathrm{ab}$ \\
\hline Kepsut-99 & $156.9 \mathrm{ab}$ & $14.3 \mathrm{f}$ & $5.46 \mathrm{~b}$ & 136.1 bc & $68.94 a b$ \\
\hline Cumhuriyet-99 & 139.4 bc & 16.7 ef & $4.23 \mathrm{bcd}$ & $107.0 \mathrm{de}$ & 81.66 a \\
\hline Sarısu & $166.7 \mathrm{a}$ & $21.8 \mathrm{~cd}$ & $5.13 \mathrm{bc}$ & $107.6 \mathrm{de}$ & $76.35 a b$ \\
\hline Özberk-82 & 174.6 a & $27.1 \mathrm{~b}$ & $3.50 \mathrm{~cd}$ & $123.5 \mathrm{~cd}$ & $73.04 \mathrm{ab}$ \\
\hline Muganlı-57 & $159.2 a b$ & $24.3 \mathrm{bc}$ & $5.23 \mathrm{~b}$ & $125.0 \mathrm{~cd}$ & $74.76 a b$ \\
\hline Hatipoğlu & 138.9 bc & $14.0 \mathrm{f}$ & $7.90 \mathrm{a}$ & $160.2 a b$ & $66.24 b$ \\
\hline Arslanbey & $133.2 \mathrm{c}$ & $33.5 \mathrm{a}$ & $2.93 \mathrm{~d}$ & $151.2 \mathrm{ab}$ & $78.25 a b$ \\
\hline Boydak & $158.1 \mathrm{ab}$ & $33.8 \mathrm{a}$ & $4.80 \mathrm{bc}$ & $148.5 \mathrm{abc}$ & 80.99 a \\
\hline Orhangazi-99 & $159.7 \mathrm{ab}$ & 19.9 de & $3.52 \mathrm{~cd}$ & $97.4 \mathrm{e}$ & $76.88 \mathrm{ab}$ \\
\hline $\begin{array}{l}\text { Varyasyon katsayısı } \\
\text { (\%) }\end{array}$ & 8.18 & 10.47 & 18.38 & 10.50 & 8.72 \\
\hline Çeşit & $*$ & $* *$ & $* *$ & $* *$ & $*$ \\
\hline
\end{tabular}

Farklı susam çeşitleri üzerinde yapılan çalışmalarda; Uzun ve Çağırgan (2001), bitki boyunu $93.7-120.0 \mathrm{~cm}$ arasında, Uzun ve Furat (2005), 80-193 cm, Yılmaz ve ark. (2005), 101.9-126.6 cm ve Çağırhan ve Silme (2009), 102$177 \mathrm{~cm}$ arasında tespit etmişlerdir. Bulgularımız, birçok araştırıcının bulgularından daha yüksek bulunmuştur. Bitki boyu bilindiği gibi farklı ekolojik koşullar, çeşit, ekim sıkığı, ekim zamanına ve genetik özeliğe bağı olarak değişebilen bir parametredir.

Tablo 1 incelendiğinde ilk dal yüksekliği bakımından çeşitler arasında \% 1 düzeyinde istatistiksel olarak önemli farklılıkların olduğu görülmektedir. Denemede, ilk dal yüksekliği $33.8 \mathrm{~cm}$ ile en yüksek Boydak çeşidinden elde edilmiştir. Arslanbey $(33.5 \mathrm{~cm})$ çeşidi ile Boydak çeşidi arasında istatistiksel olarak farklılığın olmadığı aynı grup içerisinde yer aldığı belirlenmiştir. En düşük ilk dal yüksekliği ise $14.0 \mathrm{~cm}$ ile Hatipoğlu çeşidinden elde edilirken, Tanas ve Kepsut-99 çeşitleri ile istatistiksel olarak önemli bir farklığın olmadığı ve aynı Duncan grubunda yer aldığı görülmektedir (Tablo 1).

Çok sayıda susam çeşidi üzerinde yapılan çalışmalarda; Kurt (2015), en yüksek ilk dal yüksekliğini Cumhuriyet-99 (56.07 cm) çeşidinden, Hatipoğlu (2016), Arslanbey (9.9 $\mathrm{cm})$ çeşidinden elde ettiklerini bildirmişlerdir. Bulgularımız, Kurt (2015)' in bulgularından düşük, Hatipoğlu (2016)' nun bulgularından ise yüksek 
bulunmuştur. Bununla birlikte Hatipoğlu ile benzer olarak farklı çeşitler arasında ilk dal yüksekliği bakımından öne çıkan çeşit araştırma bulgularımızda olduğu gibi Arslanbey çeşidi olmuştur.

Tablo 2. Susam çeşitlerinde kapsül uzunluğu, 1000 tohum ağırlığı, tohum verimi, yağ oranı ve yağ verimi ortalama değerleri ve Duncan grupları

Table 2. Average values capsule lenght, thousand seed weight, seed yield, oil content and oil yield in sesame varieties and Duncan groups

\begin{tabular}{llllll}
\hline Çeşitler & $\begin{array}{l}\text { Kapsül uzunluğu } \\
\text { (cm) }\end{array}$ & $\begin{array}{c}\text { Bin tohum } \\
\text { ağırlığı } \mathbf{( g )}\end{array}$ & $\begin{array}{r}\text { Tohum verimi } \\
(\mathbf{k g} / \mathbf{d a})\end{array}$ & $\begin{array}{c}\text { Yağ oranı } \\
(\%)\end{array}$ & $\begin{array}{c}\text { Yağ verimi } \\
(\mathbf{k g} / \mathbf{d a})\end{array}$ \\
\hline Tanas & $3.39 \mathrm{ab}$ & $3.66 \mathrm{~d}$ & $188.7 \mathrm{bc}$ & $35.6 \mathrm{ab}$ & $67.5 \mathrm{bcd}$ \\
Kepsut-99 & $3.42 \mathrm{ab}$ & $3.73 \mathrm{~cd}$ & $156.0 \mathrm{cde}$ & $36.1 \mathrm{ab}$ & $56.6 \mathrm{cde}$ \\
Cumhuriyet-99 & $3.52 \mathrm{a}$ & $3.68 \mathrm{~d}$ & $127.9 \mathrm{e}$ & $33.8 \mathrm{~b}$ & $43.2 \mathrm{e}$ \\
Sarısu & $3.30 \mathrm{~b}$ & $3.77 \mathrm{~cd}$ & $153.8 \mathrm{cde}$ & $34.4 \mathrm{ab}$ & $52.9 \mathrm{de}$ \\
Özberk-82 & $3.43 \mathrm{ab}$ & $3.95 \mathrm{bc}$ & $182.9 \mathrm{bcd}$ & $34.3 \mathrm{ab}$ & $63.2 \mathrm{cde}$ \\
Muganlı-57 & $3.40 \mathrm{ab}$ & $4.03 \mathrm{~b}$ & $136.0 \mathrm{de}$ & $35.1 \mathrm{ab}$ & $47.7 \mathrm{de}$ \\
Hatipoğlu & $3.08 \mathrm{c}$ & $4.30 \mathrm{a}$ & $220.4 \mathrm{ab}$ & $34.2 \mathrm{ab}$ & $75.2 \mathrm{abc}$ \\
Arslanbey & $3.55 \mathrm{a}$ & $3.64 \mathrm{~d}$ & $205.1 \mathrm{ab}$ & $36.6 \mathrm{ab}$ & $87.5 \mathrm{ab}$ \\
Boydak & $3.12 \mathrm{c}$ & $3.80 \mathrm{~cd}$ & $247.0 \mathrm{a}$ & $35.9 \mathrm{ab}$ & $89.6 \mathrm{a}$ \\
Orhangazi-99 & $3.36 \mathrm{ab}$ & $3.71 \mathrm{~d}$ & $134.6 \mathrm{de}$ & $38.1 \mathrm{a}$ & $51.0 \mathrm{de}$ \\
\hline Varyasyon katsayısı (\%) & 2.93 & 3.15 & 14.70 & 5.67 & 17.92 \\
\hline Çeşit & $* *$ & $* *$ & $* *$ & $*$ & $* *$ \\
\hline
\end{tabular}

$*^{*},{ }^{*}$ : Sırasıyla 0.05 ve 0.01 olasılık düzeylerinde önemli olup aynı harf ile gösterilen ortalamalar arasında istatistiki olarak fark yoktur.

Yan dal sayısı bakımından çeşitler arasında \%1 düzeyinde istatistiksel olarak önemli farklılıkların olduğu görülmektedir. Denemede, en fazla yan dal sayısı 7.90 adet/bitki ile Hatipoğlu çeşidinden elde edilmiştir. En düşük yan dal sayısı ise Arslanbey (2.93 adet/bitki) çeşidinden elde edilmiştir.

Farklı susam çeşit ve genotipleri üzerinde yapılan araştırmalarda; Alperen (2013), en fazla yan dal sayısını Konya Çumra (5.12 adet) çeşidinden, Kurt (2015), Orhangazi-99 (5.9 adet ) çeşidinden, Akpınar (2017), Hatipoğlu (5.2 adet) çeşidinden, Hatipoğlu (2016), Boydak (6.9 adet/bitki) çeşidinden, Toprak (2017), Şırnak-Cizre-Koruh (5.40 adet/bitki) genotipinden, Yaraş (2017); Balıkesir (16.3 adet) genotipinden ve Ekinci (2018), Akziyaret (4.20 adet/ bitki) çeşidinden elde ettiklerini bildirmişlerdir. Bulgularımız bazı araştırıcıların tespitleri ile benzerlik gösterirken bazılarından daha yüksek bazılarından ise daha düşük olmuştur. Susam bitkisinde yan dal sayısı özelliğinin çeşitlere, iklim koşullarına ve sulama zamanı gibi özelliklere bağlı olarak değişiklik gösterdiği bilinmektedir.Tablo 1 incelendiğinde kapsül sayısı bakımından çeşitler arasında \%1 düzeyinde istatistiksel olarak önemli farklılıkların olduğu görülmektedir. Denemede en fazla kapsül sayısı Tanas (162.3 adet) çeşidinden elde edilirken, en az kapsül sayısı ise 97.4 adet ile Orhangazi-99 çeşidinden elde edilmiştir. Susam çeşit ve genotipleri üzerinde yapılan çalışmalarda kapsül sayısını; Uzun ve Furat (2005), 96-237 adet/bitki, Cürat (2010), 38.0-163.8 adet/bitki, Öz ve Karasu (2010),
78.1-114.3 adet/bitki, Silme (2011), 12-127.6 adet/bitki, Şahin (2014), 12.1-37.4 adet/bitki ve Akpınar (2017), 25.3-56.0 adet/bitki arasında tespit etmişlerdir. Bulgularımız söz konusu araştırıcıların birçoğunun bulgularından yüksek bulunmuştur.

Tohum sayısı bakımından çeşitler arasında \%5 düzeyinde istatistiksel olarak önemli farklııkların olduğu belirlenmiştir. Denemede, tohum sayısı en fazla Cumhuriyet-99 (81.6 adet/kapsül) çeşidinden elde edilirken, Boydak çeşidi ile aynı Duncan grubunda yer aldığı tespit edilmiştir.

Tohum sayısı bakımından en düşük değer ise Hatipoğlu çeşidinden 66.2 adet/kapsül olarak tespit edilmiştir. Yaraş (2017) yaptığı çalışmada bazı susam çeşitlerinde kapsülde tohum sayısını en fazla Osmanlı-99 (66.8 adet/kapsül) çeşidinden, Bilmez (2015), Muganlı-57 (74.7 adet/kapsül) çeşidinden ve Hatipoğlu (2016), Arslanbey (72.0 adet/kapsül) çeşidinden belirlediklerini bildirmişlerdir. Araştırma sonuçlarımız, söz konusu araştırıcıların bulgularından daha yüksek bulunmuştur.

Bu çalışmada, kapsül uzunluğu bakımından çeşitler arasında \%1 düzeyinde istatistiksel olarak önemli farklııkların olduğu tespit edilmiştir. Denemede en uzun kapsüller Arslanbey $(3.55 \mathrm{~cm})$ çeşidinden elde edilirken Cumhuriyet-99 çeşidi ile istatistiksel olarak farklılığın olmadığı aynı Duncan grubunda yer aldığı tespit edilmiştir. En kısa kapsül uzunluğu ise Hatipoğlu (3.08 $\mathrm{cm}$ ) çeşidinden elde edilmiş olup Boydak çeşidi ile aynı Duncan grubunda yer almıştır. 
Tarla bitkilerinde verim ve verim unsurları olarak kabul edilen bitki boyu, dal sayısı, kapsül sayısı, kapsül uzunluğu, tane sayısı ve bin tane ağırlığı gibi özellikler genetik olarak belirlenmekle birlikte çevre şartları ve yetiştirme tekniği uygulamalarına göre önemli farklııklar ortaya çıkabilmektedir. Farklı susam çeşitleri üzerinde yapılan çalışmalarda; Akpınar (2017), en uzun kapsül uzunluğuna sahip çeşidin Arslanbey $(2.83 \mathrm{~cm})$ çeşidi, Yaraş (2017), kapsül uzunluğunun $2.5-3.5 \mathrm{~cm}$ arasında değiştiğini tespit ettiklerini bildirmişlerdir. Kapsül uzunluğuna dair elde ettiğimiz sonuçlar, Akpınar (2017)' ın bulgularından yüksek iken, Yaraş (2017)' ın bulguları ile aynı sınırlar içerisindedir.

Tablo 2 incelendiğinde 1000 tohum ağırlığı bakımından çeşitler arasında \%1 düzeyinde istatistiksel olarak önemli farklılıkların olduğu görülmektedir. Denemede en yüksek 1000 tohum ağılığı 4.30 g ile Hatipoğlu çeşidinden elde edilirken, en düşük 1000 tohum ağırlığı ise $3.64 \mathrm{~g}$ ile Arslanbey çeşidinden elde edilmiştir. Ancak, Tanas, Cumhuriyet-99, Arslanbey ve Orhangazi-99 çeşitleri ile aynı Duncan grubunda yer aldığı Tablo 2' de görülmektedir.Diğer farklı çalışmalarda bin tohum ağırlı̆ıını; Hatipoğlu (2016), en yüksek Hatipoğlu (3.3 g) çeşidinden, Bilmez (2015), Muganlı-57 (2.6 g) çeşidinden, Ekinci (2018), Hatipoğlu (2.50 g) çeşidinden, Alperen (2013), Pakistan (3.35 g) çeşidinden olduğunu saptamıştır. Akpınar (2017), Hatipoğlu (3.9 g) çeşidinden, Kurt (2015) ise yaptığı çalışmada 1000 tohum ağırlığı en yüksek Manisa-Salihli (3.79 g) çeşidinden saptamıştır.

Bulgularımız araştırmacıların sonuçlarına göre yüksek bulunmuştur. Sonuçların yüksek bulunmasında çeşit özelikleri, bakım ve iklim faktörlerinin önemli etkenler olduğu düşünülmektedir.

Tohum verimi bakımından çeşitler arasında \% 1 düzeyinde istatistiksel olarak önemli farklılıkların olduğu görülmektedir. Denemede, en yüksek tohum verimi $247.0 \mathrm{~kg} / \mathrm{da}$ ile Boydak çeşidinden elde edilirken, en düşük tohum verimi ise $127.9 \mathrm{~kg} / \mathrm{da}$ Cumhuriyet-99 çeşidinden elde edilmiştir. Yapılan farklı çalışmalarda; susam çeşit ve genotiplerinin tohum verimleri 115.4$124.7 \mathrm{~kg} / \mathrm{da}$ (Baydar, 2005), 55.7-118.7 kg/da (Öz ve Karasu, 2010), 67.71-113.53 kg/da (Öztürk ve Şaman, 2012) ve $111.2-154.8 \mathrm{~kg} / \mathrm{da}$ (Arslan ve ark., 2014) arasında değiştiği kaydedilmiştir. Ayrıca, Akpınar (2017), yaptığı çalışmada kullandığı susam çeşitlerinden (Hatipoğlu, Kepsut-99, Osmanlı-99, Muganlı-57, Orhangazi-99, Tan-99, Cumhuriyet-99, Arslanbey, Batem Uzun, Gölmarmara) en yüksek tohum verimini Hatipoğlu (77.9 kg/da) çeşidinden ve Ekinci (2018), bazı susam genotipleri (Arslanbey, Kepsut-99, Cumhuriyet-99, Orhangazi-99, Hatipoğlu, Muganlı-57, Akziyaret, Andırın, Burkina Faso, Köseli) ile yaptığı çalışmada en fazla tohum verimini Cumhuriyet-99 $(92.88 \mathrm{~kg} / \mathrm{da})$ çeşidinden tespit ettiklerini bildirmişlerdir. Tohum verimine ait araştırma bulgularımız söz konusu araştırıcı bulgularından oldukça yüksek tespit edilmiştir. Tohum verimi pek çok sayıda özelliğin karşılıklı etkileşimi sonucu meydana gelen bir değerdir. Tohum verimlerinin çeşitlere göre degişiklik göstermesi; genetik yapılarının farklılığından, iklim ile toprak faktörlerinden farklı düzeyde etkilenmelerinden ve doğru şekilde ve zamanında yapılan kültürel uygulamalardan kaynaklanmaktadır.

Yağ oranı bakımından çeşitler arasında \% 5 düzeyinde istatistiksel olarak önemli farklılıkların olduğu görülmektedir. Denemede en yüksek yağ oranı \% 38.1 ile Orhangazi-99 çeşidinden elde edilirken, en düşük yağ oranı ise \% 33.8 ile Cumhuriyet-99 çeşidinden elde edildiği Tablo 2' da görülmektedir.

Farklı susam çeşitleri üzerinde yapılan çalışmalarda; Hatipoğlu (2016), yaptığı çalışmada susam çeşitlerinden en yüksek yağ oranını Hatipoğlu (\% 50.6) çeşidinden, Akpınar (2017), en fazla yağ oranını Orhangazi-99 (\% 47.1) çeşidinden elde ettiklerini bildirmişlerdir. Ayrıca susamın yağ oranına ilişkin daha önceki çalışmalarda; Baydar (2005), \% 45.7-52.4, Yılmaz ve ark. (2005), \% 43.42-49.67, Hiremath ve ark. (2007), \% 46.1-53.8, Uzun ve ark. (2008), \% 41.3-62.7 ve Ağaç (2017), yağ oranını \% 55.7 ile 49.5 arasında tespit etmişlerdir. Çalışma sonuçlarımız yağ oranına dair diğer araştırıcıların elde ettikleri bulgulardan daha düşük bulunmuştur. Bunun sebebi olarak, susam bitkisinde yağ oranı özelliğinin susam çeşitlerinde güneşlenme süresine, günlük sıcaklık değişimine ve bitkinin ana ve ikinci ürün yetiştiriciliğine bağlı olarak değişiklik gösterebileceği kanaatine ulaşılmıştır.

Tablo 2 incelendiğinde yağ verimi bakımından çeşitler arasında \% 1 düzeyinde istatistiksel olarak önemli farklılıkların olmadığı görülmektedir. Denemede en yüksek yağ verimi $89.6 \mathrm{~kg} /$ da ile Boydak çeşidinden elde edilmiştir. Yağ verimine ilişkin daha önce yapılan çalışmalarda; Baydar (2005), 52.5-65.2 kg/da ve Ağaç (2017), $16.5-35.8 \mathrm{~kg} / \mathrm{da}$ arasında tespit ettiklerini bildirmişlerdir. Ayrıca, pek çok araştırmacı çok sayıda susam çeşit ve genotipi üzerinde yaptıkları çalışmalarda; Alperen (2013), en fazla yağ verimini Mersin Mut (60.92 $\mathrm{kg} / \mathrm{da}$ ) çeşidinden, Kurt (2015), Adana-Sarıçam (101.9 $\mathrm{kg} / \mathrm{da}$ ) çeşidinden, Hatipoğlu (2016) Arslanbey ( 56.2 $\mathrm{kg} / \mathrm{da}$ ) çeşidinden, Ekinci (2018), Arslanbey $(56.50 \mathrm{~kg} / \mathrm{da}$ ) çeşidinden elde ettiklerini bildirmişlerdir. Bulgularımız; Kurt (2015)'in verilerinden düşük, Baydar (2005), Alperen (2013), Hatipoğlu (2016), Ağaç (2017), Akpınar (2017) ve Ekinci (2018)'nin verilerinden yüksek olmuştur. Yağ verimi, çevre koşullarından çok fazla etkilenen tane 
verimi ve genetik katkının fazla olduğu yağ oranı tarafından belirlenmektedir.

\section{Karakterler arası ikili ilişkiler (Korelasyon analizi)}

Yapılan çalışmada incelenen parametreler arasındaki ikili ilişkiler ayrı ayrı değerlendirilmiş, elde edilen katsayılar Tablo 3' de verilmiştir. Tablo incelendiğinde; bitki boyu ile bitki başına kapsül sayısı arasında \% 5 seviyesinde önemli ve pozitif bir ilişki olduğu tespit edilmiştir. İlk dal yüksekliği ile bitki başına yan dal sayısı arasında \% 1 seviyesinde önemli ve negatif, tohum verimi (\% 5) ve yağ verimi (\% 1) arasında ise önemli ve pozitif bir ilişkinin olduğu Tablo 3' de görülmektedir. Bitki başına yan dal sayısı ile bitki başına kapsül sayısı ve bin tohum ağırlığı arasında \% 5 düzeyinde istatistiksel olarak önemli ve olumlu bir ilişkinin olduğu tespit edilirken, kapsülde tane sayısı (\% 5) ve kapsül uzunluğu (\% 1) gibi parametreler arasındaki ilişkinin ise önemli ve negatif ilişkiler olduğu belirlenmiştir.

Tablo 3. Incelenen karakterler arasındaki ikili ilişkiler

Table 3. Bilateral relations between examined characters

\begin{tabular}{|c|c|c|c|c|c|c|c|c|c|c|}
\hline & $\mathrm{BB}$ & IDY & YDS & $\mathrm{KS}$ & TS & $\mathrm{KU}$ & BTA & TV & $\mathrm{YO}$ & $\mathrm{YV}$ \\
\hline BB & 1 & 0.109 & -0.214 & $-0.334^{*}$ & 0.163 & 0.184 & 0.164 & -0.009 & -0.032 & -0.009 \\
\hline IDY & & 1 & $-0.538^{* *}$ & 0.013 & 0.243 & 0.109 & -0.111 & $0.358^{*}$ & 0.154 & $0.514^{* *}$ \\
\hline YDS & & & 1 & $0.404^{*}$ & $-0.319^{*}$ & $-0.639^{* *}$ & $0.409^{*}$ & 0.093 & -0.236 & -0.037 \\
\hline KS & & & & 1 & -0.218 & $-0.323^{*}$ & 0.082 & $0.558^{* *}$ & -0.013 & $0.550^{* *}$ \\
\hline TS & & & & & 1 & $0.444^{* *}$ & -0.106 & 0.004 & -0.002 & -0.032 \\
\hline $\mathrm{KU}$ & & & & & & 1 & -0.250 & -0.290 & -0.023 & -0.106 \\
\hline BTA & & & & & & & 1 & 0.245 & $-0.371^{*}$ & 0.142 \\
\hline TV & & & & & & & & 1 & -0.112 & $0.740^{* *}$ \\
\hline YO & & & & & & & & & 1 & 0.220 \\
\hline YV & & & & & & & & & & 1 \\
\hline
\end{tabular}

* 0.05 düzeyinde önemli, ** 0.01 düzeyinde önemli, BB: Bitki boyu, IDY: İlk dal yüksekliği, YDS: Yan dal sayıSı, KS: Kapsül sayısı, TS: Tohum sayısı, KU: Kapsül uzunluğu, BTA: Bin tohum ağırlı̆ı, TV: Tohum verimi, YO: Yağ oranı, YV: Yağ verimi.

Bitki başına kapsül sayısı ile kapsül uzunluğu arasında \% 5 seviyesinde önemli ve negatif bir ilişki söz konusu iken, tohum verimi ve yağ verimi ile aralarında $\% 1$ seviyesinde önemli ve pozitif bir ilişkinin olduğu kaydedilmiştir. Susam kapsüllerinde tohum sayısı ile kapsül uzunluğu arasında \% 1 seviyesinde önemli ve olumlu bir ilişki gözlemlenirken, bin tohum ağırlığı ile yağ oranı arasında \% 5 seviyesinde önemli ve negatif bir ilişkinin olduğu tespit edilmiştir. Ayrıca, susamın tohum verimi ile yağ verimi arasında \% 1 seviyesinde önemli ve olumlu bir ilişkinin olduğu, tohum verim arttıkça yağ veriminde de paralel olarak artışların olduğu belirlenmiştir.

\section{SONUÇ ve ÖNERILER}

Susamda incelenen veriler, bitkilerin çeşit ve genotiplerine, ekim zamanına, sulama durumuna, bitkilerin hastalıklı ve sağlıklı olma durumuna, yetiştirme ve çevre koşullarına bağlı olarak değişmektedir. Bundan dolayı ıslah ve adaptasyon çalışmaları sonucunda geliştirilen çeşitlerin çiftçilerimizin kullandıkları yerel popülasyonların sahip oldukları genetik özellikler farklı ekolojik şartlarda muhtemel farklııklar göstermektedirler. Dolayısıyla susamda yapılan çalışmalardan elde edilen değerler oldukça geniş aralıklarda değişkenlik gösterebilmektedir.

Araştırma sonucunda; diğer çeşitlere göre tohum $(247.41 \mathrm{~kg} / \mathrm{da})$ ve yă verimi $(89.66 \mathrm{~kg} / \mathrm{da})$ bakımından yüksek performans gösteren Boydak çeşidi, Diyarbakır iklim ve toprak koşullarında ikinci ürün susam yetiştiriciliğinde rahatlıkla tavsiye edilebilir. İkinci ürün susam tarımına uygun, sulu koşullarda yüksek verim potansiyeline sahip tescilli susam çeşitlerinin bölge üretimde yer alması adaptasyonu ve verimi yüksek susam çeşitlerinin ekim nöbetinde yer alması tarımsal üretime önemli katkı sağlayacaktır. Elde edilen sonuçların, bölgede yapılacak olan sonraki çalışmalara 1şık tutabileceği, öne çıkan verimli çeşitlerin bölgemiz tarımına kazandırılması bakımından önem arz eden bir çalışma olduğu düşünülmektedir.

\section{ÖZET}

Amaç: Bu çalışmada, 2017 yılında ikinci ürün olarak, Diyarbakır-Kayapınar ekolojik koşullarında bazı susam çeşitlerinin tarımsal ve kalite özelliklerinin araştırılması amaçlanmıştır. 
Yöntem ve Bulgular: Deneme, Tesadüf Blokları Deneme Deseni' ne göre üç tekerrürlü olarak kurulmuştur. Araştırmada 10 tescilli susam çeşidi (Arslanbey, Boydak, Hatipoğlu, Sarısu, Tanas, Orhangazi-99, Kepsut 99, Muganlı 57, Özberk 82 ve Cumhuriyet 99) kullanılmıştır. Araştırma sonucunda; en yüksek bitki boyu $(174.6 \mathrm{~cm})$ Özberk-82 çeşidinden, en fazla yan dal sayısı (7.90 adet/bitki) Hatipoğlu, en fazla kapsül sayısı (162.3 adet/bitki) Tanas çeşidinden elde edilirken, kapsülde en fazla tohum sayısı (81.6 adet) Cumhuriyet-99, en fazla kapsül uzunluğu $(3.55 \mathrm{~cm}$ ) Arslanbey, en fazla 1000 tohum ağırlığı ( $4.30 \mathrm{~g})$ Hatipoğlu ve en fazla yağ oranı (\% 38.1) ise Orhangazi-99 çeşidinden elde edilmiştir. Çalışmada, en fazla ilk dal yüksekliği $(33.8 \mathrm{~cm})$, tohum verimi $(247.0 \mathrm{~kg} / \mathrm{da})$ ve yağ verimi $(89.6 \mathrm{~kg} / \mathrm{da})$ Boydak susam çeşidinden elde edilmiştir.

Genel Yorum: Çeşitlerin tarımsal özellikleri farklılıklar göstermiş ve en yüksek tohum verimi Boydak susam çeşidinden elde edilmiştir.

Çalışmanın Önemi ve Etkisi: Türkiye'de yetiştirilen bazı tescilli susam çeşitlerinin Diyarbakır ekolojik koşullarına adaptasyonunun belirlendiği çalışma sonucunda; tohum ve yağ verimi bakımından yüksek performans gösteren Boydak çeşidi, Diyarbakır iklim ve toprak koşullarında ikinci ürün susam yetiştiriciliği için önerilebilir.

Anahtar Kelimeler: Çeşit, Sesamum indicum L., yağ oranı, verim.

\section{TEŞEKKÜR}

Bu çalışma "Diyarbakır ekolojik koşullarında tescilli bazı susam (Sesamum indicum L.) çeşitlerinin tarımsal ve kalite özelliklerinin araştırılması" isimli Veysi BÜRKÜK' ün Yüksek Lisans tez çalışmasının özeti niteliğindedir.

\section{ÇIKAR ÇATIŞMA BEYANI}

Makale yazarları arasında herhangi bir çıkar çatışması bulunmamaktadır.

\section{ARAŞTIRMACILARIN KATKI ORANI BEYANI}

Yazarlar makaleye eşit oranda katkı sağlamıştır.

\section{KAYNAKLAR}

Ağaç HÜ (2017) Şanlıurfa Koşullarında Bazı Susam (Sesamum indicum L.) Genotiplerinin Morfolojik ve Fizyolojik Özelliklerinin Verim ve Verim Unsurlarına Etkisi. Yüksek Lisans Tezi , Harran Üniversitesi,Fen Bilimleri Enstitüsü, Tarla Bitkileri Anabilim Dalı, $103 \mathrm{~s}$.

Akpınar K (2017) Susam Bitkisinin (Sesamum indicum L.) Kahramanmaraş Ekolojisinde Agronomik ve
Teknolojik Özelliklerinin İncelenmesi. Yüksek Lisans Tezi, Kahramanmaraş Sütçü İmam Üniversitesi, Fen Bilimleri Enstitüsü, Tarla Bitkileri Ana Bilim Dalı, $63 \mathrm{~s}$.

Alperen H (2013) Türkiye'nin Farklı Yetiştirilme Bölgelerinden Toplanan Yerel Susam (Sesamum indicum L.) Çeşitlerinin Aynı Ekolojik Sartlarda Yetiştirilerek Besin İçeriğinin Belirlenmesi. Yüksek Lisans Tezi, Erciyes Üniversitesi, Fen Bilimleri Enstitüsü, Gıda Mühendisliği Anabilim Dalı, $121 \mathrm{~s}$.

Anonim (2018) Bitkisel Yağ Sanayicileri Derneği Türkiye İstatistikleri, www.bysd.org (Erişim Tarihi: 12.12.2018).

Anonim (2019) Diyarbakır Meteoroloji Bölge Müdürlüğü. Anonim(2020a) www.fao.org. (Erişim Tarihi: 13.02.2020)

Anonim (2020b) Türkiye İstatistik Kurumu. (Erişim Tarihi: 14.02.2020).

Arıoğlu H, Kolsarıcı Ö, Kurt O, Çalışkan S, Aslan M, İşler N, Göksoy AT, Başalma D, Baydar H, Özer H, Uzun B, Önemli F, Kaya $Y$, Sincik M, Öztürk Ö, Kıllı F, Tunçtürk R, Öztürk $E$, illker $E$, Aslanoğlu $F$, Aytaç S, Onat B, Kurt C, Çubukçu P, Bakal H (2020) Yağı ı Tohumlar Üretiminde Mevcut Durum ve Gelecek. Türkiye Ziraat Mühendisliği IX. Teknik Kongresi Bildiriler Kitabı-1. 13-17 Ocak, Ankara, pp 419-438.

Arslan H, Hatipoğlu H, Karakuş M (2014) Şanlıurfa yöresinde tarımı yapılan susam genotiplerinden seçilen bazı hatların ikinci ürün koşullarında verim ve verim unsurlarının belirlenmesi Turk. J. Agric. Res. 1: 109-116.

Baydar H (2005) Susamda (Sesamum indicum L.) verim, yağ, oleik ve linoleik tipi hatların tarımsal ve teknolojik özellikleri, Akdeniz üniversitesi Ziraat Fakültesi Dergisi 18: 267- 272.

Bilmez A (2015) Türkiye'nin Farklı Bölgelerinden Sağlanan Susam (Sesamum indicum L.) Populasyonlarının Agromorfolojik Özellikler Bakımından Karşılaştırılması. Yüksek Lisans Tezi, Dicle Üniversitesi, Fen Bilimleri Enstitüsü, Tarla Bitkileri Ana Bilim Dalı,73 s.

Cürat D (2010) Kilis ve Yöresinde Yetiştirilen Yerel Susam (Sesamum indicum L.) Çeşitlerinin Verim ve Verim Unsurlarının Belirlenmesi. Yüksek Lisans Tezi ,Siirt Üniversitesi, Fen Bilimleri Enstitüsü, Ana Bilim Dalı, $47 \mathrm{~s}$.

Çağırhan Mi, Silme RS (2009) Seçilmiş mutant ve dünya susam materyalinin verim ve verim komponentleri bakımından değerlendirilmesi. $X$. 
Ulusal Nükleer Bilimler ve Teknolojileri Kongresi, 6-9 Ekim,Muğla, pp 312-316.

Düzgüneş O, Kesici T, Kavuncu O, Gürbüz $F$ (1987) Araştırma ve Deneme Metotları (Istatistik Metotları 2). Ankara Üniversitesi, Ziraat Fakültesi Yayınları, No: 1021, Ders Kitabı N. 295, Ankara, $381 \mathrm{~s}$.

Ekinci BN (2018) Kahramanmaraş Koşullarında Ana Ürün Olarak Bazı Soya (Glycine max L.(Merrill) ve Susam (Sesamum indicum L.) Çeşitlerinin Verim ve Verim Unsurlarının Belirlenmesi. Yüksek Lisans Tezi Kahramanmaraş Sütçü İmam Üniversitesi, Fen Bilimleri Enstitüsü, Tarla bitkileri Anabilim Dalı, $83 \mathrm{~s}$.

Gençer O (1993) Genel Tarla Bitkileri. Çukurova Üniversitesi, Ziraat Fakültesi Yayınları No:42, p,62-66. Adana.

Hatipoğlu H (2016) Siirt İkinci Ürün Koşullarında Bazı Susam (Sesamum indicum L.) Çeşitlerinin Verim ve Verim Unsurlarının Belirlenmesi. Yüksek Lisans Tezi, Siirt Üniversitesi, Fen Bilimleri Enstitüsü,Tarla bitkileri Anabilim Dalı, $53 \mathrm{~s}$.

Hiremath SC, Patil CG, Patil KB, Nagasampige MH (2007) Genetic diversity of seed lipid content and fatty acid composition in some species of Sesamum $\mathrm{L}$. (Pedaliaceae). African Journal of Biotechnology 6(5): 539-543.

IBM C (2013). IBM SPSS Statistics for Windows, Version 22.0.

Kurt C (2015) Bazı Yerel Susam (Sesamum indicum L.) Çeşit ve Populasyonlarının Agronomik, Kalite ve Moleküler Karakterizasyonu. Doktora Tezi, Çukurova Üniversitesi, Fen Bilimleri Enstitüsü, Tarla Bitkileri Ana Bilim Dalı, $118 \mathrm{~s}$.

Öz A, Karasu B (2010) Bazı susam (Sesamum indicum L.) çeşit ve hatlarının Bursa koşullarında performanslarının belirlenmesi. Harran Üniversitesi Z.F. Dergisi 14(2): 21-27.

Öztürk Ö, Şaman O (2012) ỉkinci ürün susamda farklı bitki sıklıklarının verim ve verim unsurları üzerine etkileri. Tarım Bilimleri Araştırma Dergisi 5(1): 118-123.
Silme SR, Çağırgan MǴ (2009). Seçilmiş mutant ve dünya susam materyalinin verim ve verim komponentleri bakımından değerlendirilmesi. $X$. Ulusal Nükleer Bilimler ve Teknoloji Kongresi, 6 9 Ekim,Muğla, pp 333-339.

Şahin G (2014) Türkiye'de üretimi azalan önemli bir yağ bitkisi susam. İnsan ve Toplum Bilimleri Araştırmaları Dergisi 3 (2): 404-433.

Toprak T (2017) Türkiye' nin Farklı Bölgelerinden Toplanan Susam (Sesamum indicum L.) Genotiplerinin Verim ve Verim Özelliklerinin Belirlenmesi. Yüksek Lisans Tezi, Dicle Üniversitesi Fen Bilimleri Enstitüsü, Tarla Bitkileri Anabilim Dalı, $72 \mathrm{~s}$

Uzun B, Çağırgan i (2001) Farklı ekim sıklıklarının determinant ve indeterminant susam(Sesamum indicum L.) tiplerine etkisi. Akdeniz Üniversitesi Ziraat Fakültesi Dergisi 14(1): 23-27.

Uzun B, Furat U (2005) Türk susam koleksiyonunun morfolojik ve tarımsal özellikler bakımından değerlendirilmesi, Türkiye VI. Tarla Bitkileri Kongresi, Cilt I. 5-9 Eylül, Antalya, pp 431-436.

Uzun B, Arslan Ç, Furat Ş (2008) Variation in fatty acid compositions, oil content and oil yield in a germplasm collection of sesame (Sesamum indicum L.). Journal of American Oil Chemists' Society, 85: 1135-1142.

Yaraş B (2017) Bazı Susam (Sesamum indicum L.) Genotiplerinin Tokat-Kazova Ekolojik Şartlarında Ana Ürün Verim Performanslarının Belirlenmesi. Yüksek Lisans Tezi, Gaziosmanpaşa Üniversitesi, Fen Bilimleri Enstitüsü, Tarla bitkileri Anabilim Dalı, $87 \mathrm{~s}$.

Yılmaz A, Boydak E, Beyyavaş V, Cevheri i, Haliloğlu H, Güneş A (2005) Şanlıurfa ekolojisinde ikinci ürün olarak bazı susam (Sesamum indicum L.) çeşit ve hatlarının yetiştirilme olanaklarının araştırılması, Türkiye VI. Tarla Bitkileri Kongresi, 5-9 Eylül, Antalya, pp 425-429. 